\title{
Edible Films and Coatings Functionalization by Probiotic Incorporation: A Review
}

\author{
Oana L. Pop ${ }^{1}$, Carmen R. Pop ${ }^{1}{ }^{(}$, Marie Dufrechou ${ }^{2}$, Dan C. Vodnar $\left.{ }^{1}{ }^{(}\right)$, Sonia A. Socaci ${ }^{1}{ }^{(}$, \\ Francisc V. Dulf ${ }^{3}$ (D) Fabio Minervini ${ }^{4, *} \mathbb{D}$ and Ramona Suharoschi ${ }^{1, *}$ \\ 1 Department of Food Science, University of Agricultural Sciences and Veterinary Medicine, \\ Calea Mănăştur 3-5, 400372 Cluj-Napoca, Romania; oanalelia.pop@gmail.com (O.L.C.); \\ carmen-rodica.pop@usamvcluj.ro (C.R.P.); dan.vodnar@usamvcluj.ro (D.C.V.); \\ sonia.socaci@usamvcluj.ro (S.A.S.) \\ 2 USC 1422 GRAPPE, INRA, Ecole Supérieur d'Agriculture, SFR 4207 QUASAV, 55 rue Rabelais, BP 30748, \\ 4900 Agnes Cedex 01, France; m.dufrechou@groupe-esa.com \\ 3 Department of Biochemistry, University of Agricultural Sciences and Veterinary Medicine, \\ Calea Mănăştur 3-5, 400372 Cluj-Napoca, Romania; francisc_dulf@yahoo.com \\ 4 Department of Soil, Plant and Food Science, University of Bari Aldo Moro, 70121 Bari, Italy \\ * Correspondence: fabio.minervini@uniba.it (F.M.); ramona.suharoschi@usamvcluj.ro (R.S.); \\ Tel.: +39-0805442946 (F.M.); +40-771636781 (R.S.)
}

Received: 1 December 2019; Accepted: 17 December 2019; Published: 19 December 2019

\begin{abstract}
Edible coatings and films represent an alternative packaging system characterized by being more environment- and customer-friendly than conventional systems of food protection. Research on edible coatings requires multidisciplinary efforts by food engineers, biopolymer specialists and biotechnologists. Entrapment of probiotic cells in edible films or coatings is a favorable approach that may overcome the limitations linked with the use of bioactive compounds in or on food products. The recognition of several health advantages associated with probiotics ingestion is worldwide accepted and well documented. Nevertheless, due to the low stability of probiotics in the food processing steps, in the food matrices and in the gastrointestinal tract, this kind of encapsulation is of high relevance. The development of new and functional edible packaging may lead to new functional foods. This review will focus on edible coatings and films containing probiotic cells (obtaining techniques, materials, characteristics, and applications) and the innovative entrapment techniques use to obtained such packaging.
\end{abstract}

Keywords: edible films; edible coatings; probiotics; functional food; antibacterial activity

\section{Introduction}

Edible films or coatings (edible packaging or EP) are defined by any material meant to be applied (wrapping or coating) to food in order to extend the shelf life and may be consumed together with the food. Due to the many disadvantages related to plastic films and packaging, edible films have gained popularity in the scientific world, and drawn the attention of authorities and consumers [1] concerned about environmental protection. Indeed, conventional synthetic packages have a very damaging effect on the environment [2].

$\mathrm{EP}$, especially those containing microorganisms, can be considered as a living ecosystem that selectively allows for the exchanges of respiration gases (e.g., oxygen, carbon dioxide and ethylene) between food and the atmosphere, diminishes or prevents loss of moisture and aromas and/or protects against undesired microorganisms [3].

Depending on the exact purpose, the film/coating can totally coat the food or can be applied between food constituents [4]. The materials that are utilized for the edible films/coatings production 
are biopolymers, proteins, lipids or composites. Thus, even if they are not consumed with food, they can be more rapidly and easily degraded with respect to plastic materials [5].

The main difference between coating and film is in their preparation and application process. Indeed, edible films are usually obtained in parallel to food and then applied to the surface, whereas coatings are directly prepared on food surface [6]. Both coatings and films can entrap live probiotic microorganisms.

Due to handling and hygienic limitations, EP can be combined with ecofriendly non-EP [6-8].

The utilization of films for food preservation dates back to the 12th century in China, where wax was utilized to delay moisture loss from fruits. Sixteen centuries ago, the first edible films made from soymilk were used in Japan for fruits preservation and in order to obtain a shiny surface $[9,10]$. Due to the narrow variety of materials used to protect fruits and vegetables at that time, no big interest was shown to this type of package. Refrigeration, controlled/modified atmosphere, heat or radiation sterilization, smoking have ever received stronger attention than edible packaging. Of course, food conservation methods have considerably increased and have offered unlimited opportunities to prepare, store and consume any type of food in any season. However, EP can currently be applied to a large variety of food products, with unique, tailored and innovative ways of action than conventional food preservation techniques [1].

Among various roles played by EP, physical protection [11] amplification and protection of food properties, carriers of food additives and prolongation of shelf life are the most important ones.

EP may be categorized according to the class of their constituent material. Hydrocolloids (polysaccharides and proteins) and lipids are the most used materials. Among these, polysaccharides are the easiest to purchase and more suitable to form films or coatings. The presence of a large number of hydroxyl groups and hydrogen bonds favor the formation of film. Different properties can be observed between films and coatings made of negatively charged gums (i.e., alginate, pectin, or carboxymethyl cellulose) [7].

Proteins used for EP have mostly animal origin (gelatin, casein, whey proteins, collagen or egg albumin). However, plant-derived proteins (e.g., corn, soybean, wheat, cottonseed, peanut, and rice) are also appreciated and compatible with the vegetarian diet. The film/coating forming process is started, in most of the cases, with protein denaturation using heat or $\mathrm{pH}$ adjustment, followed by a conglomeration of peptide chains through new intermolecular interactions [12]. These type of films are suitable mainly for meat products, due to their affinity to hydrophilic surfaces [13-15].

Lipids do not form cohesive films, unlike hydrocolloids. For this reason, they are used especially for coatings or in mixture with polysaccharides in order to obtain an optimized water vapor barrier [16].

The integration of different additives (i.e., probiotic microorganisms but also organic acids [17], essential oils [18], plant extracts [19], and antibacterial compounds [20]) into the EP has the benefit of ensuring slower release of these compounds to food [21]. The aim of this paper is to review the application of various types of natural EP that incorporates live probiotic microorganisms.

\section{Bioactive Molecules in EP and Perspectives in Food Industry}

EP may be used not only for their protective effect but as carriers of bioactive substances too. Some examples of bioactive molecules are: antimicrobial compounds, probiotics, anti-browning compounds, omega-3 fatty acids, and other nutraceuticals [22]. Active food packaging that incorporates bioactive molecules not only acts as a traditional protective system for the food product, but also promotes the health of consumers.

Even more, the utilization of byproducts in order to obtain the edible package or to extract a bioactive molecule that will be further incorporated into the package will sustain the economical approach [23]. Obviously, when compared with fresh fruits and vegetables, the utilization of agricultural byproducts, like fruit peels to prepare edible films, seems much more profitable from the perspective of resource recycling and environmental protection, and needs further study [24]. 
The utilization of EP that contain bioactive molecules have multiple advantages [25]. One example of EP that can sustain human health and influence the final product are fried food products. A decrease of oil intake in deep-fried food products represents a significant application of EP, namely coatings. Obesity and heart diseases have been linked to an excess of fat in food. The use of film made of methylcellulose and hydroxypropyl/methylcellulose allows for a decrease in oil absorption by food, thus helping to reduce fat intake [26].

The processing techniques used to obtain EP vary depending on the material and bioactive compounds added in the EP [27]. Legislation, polymer types, active molecules, destination and are all factors that influence the matrix choice.

\section{Probiotics in Food and Human Health}

Nowadays, probiotics are associated with a world that lives on and inside humans and animals, modulating the host's health $[28,29]$. The amount of bacteria that can be found in the human body exceeds the number of human cells by more than ten times. Due to the great impact of the gut microbiota on the human body and its health modulation, the human gastrointestinal network is also called "the other brain" [30]. The human gut hosts about 1500 bacterial species, of which about 500 species have pathogenic or probiotic traits.

The gut's influence on health, exerted by microorganisms inhabiting human body (especially some sections of the gut), starts in the womb of mother, depends on the child's delivery (C-section or vaginal) modality, milk (breast-fed or artificial milk) ingested by newborn, and afterwards, is mostly modulated by diet. Other genetic and epigenetic factors, as well as environmental drivers (geographic location, stress, physical activity, and drug intake), further modulate the balance in the gut microbiota. While being relatively stable in adulthood, during aging, the gut microbiota composition continuously changes [31]. In elderly individuals, the frequently observed decrease in the Bacteroidetes/Firmicutes ratio is correlated with functionality decline of the immune system.

Any modification in the diversity of the gut microbiota (dysbiosis) may result in the onset of certain illnesses and dysfunctions. The use of probiotic supplements is a possible, cost-effective and easy-to-use solution to counteract dysbiosis and face the pressing issue of microorganisms capable of resisting multiple antibiotics [32].

The current definition of probiotic microorganism underlines it as a viable, single or mixed, culture of bacteria or yeast which beneficially impact animal or human health when ingested in the adequate amount [33]. Members of the genera Bifidobacterium and Lactobacillus are consistently used for their probiotic effect, whereas members of the genera Streptococcus and Enterococcus contain several opportunistic pathogens [34,35]. Some yeasts, mostly Saccharomyces boulardii, are accepted for use as probiotics.

Probiotics help to prevent or, in some cases, treat diarrhea, ulcerative colitis, irritable bowel syndrome, allergies, obesity, and diabetes [36,37]. Several modes of action are well-known for probiotics; for instance, they are able to modulate nutrients absorption [38], act as a barrier against pathogenic bacteria at the level of intestinal mucosa [39], have an impact on the immune system [40], and influence the gut-brain axis [41]. Some mechanisms of action exerted by probiotic microorganisms are mediated by their metabolites, such as molecules with antimicrobial activity (e.g., organic acids, ethanol, hydrogen peroxide, and bacteriocins) and short chain fatty acids that are used by enterocytes as nutrients [42].

\section{Entrapped Probiotics in EP}

In order to benefit from the consumption of probiotics, a dose of $10^{8-9}$ viable cells per day is recommended. In many products, to reach this dose is challenging due to high sensibility of probiotics to environmental conditions. Survival of probiotics depends on strain, food characteristics (e.g., pH), processing technologies, storage conditions and time [43]. Biological activities of probiotic bacteria and yeasts can be negatively affected by their loss of viability during food processing and storage. The use 
of encapsulated probiotics in edible films or coatings could favor the optimal survival of beneficial microorganisms in food. EP that incorporate probiotics display, besides those characteristics that are peculiar to all the EP, features specifically addressed to maintain the host in good health (Figure 1). In addition, since probiotic microorganisms often showed inhibitory activity towards spoilage or pathogenic bacteria, their incorporation in EP can increase food stability and safety. Food packaged in coatings or films containing probiotics may be regarded as functional food, a special group of food items that, if regularly introduced in diet, benefit health, beyond their nutritional value [44].

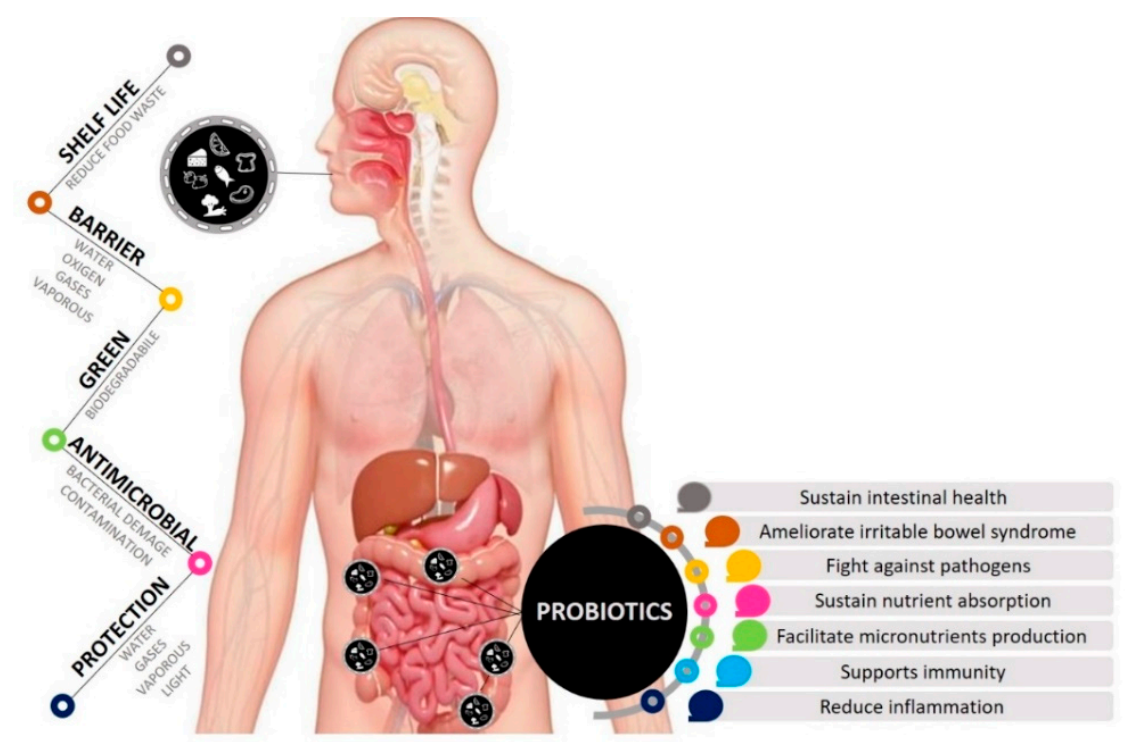

Figure 1. Characteristics of edible packaging (EP) containing probiotics and some of the most studied healthy effects exerted by probiotics.

Encapsulation of probiotics in EP may be obtained using spray drying [45] with or without protectants, spray freeze-drying or electrospray, and cross-linking gelation.

The addition of probiotics to EP is much less frequent than the addition of plant extracts. Nowadays, this technology allows widening the range of probiotic-carrier food products that vehicle probiotics, satisfying the demand for nondairy foods, fostered by vegan consumers and lactose-intolerant people [40]. In one of the first research studies about the encapsulation of probiotics in EP, Bifidobacterium animalis subsp. lactis BB-12 was entrapped in alginate and gellan-based edible coatings of apple and papaya slices. The addition of BB- 12 seemed to cause an increase in the space between the polymer chains. During 10 days of storage at $2{ }^{\circ} \mathrm{C}$, the cell density of the strain was above minimum recommended $\left(10^{6}\right.$ Colony-Forming Units/g or CFU/g) [46,47]. However, the coating containing the probiotic strain showed higher (50\%) water vapor permeability than the control coating [46].

EP containing probiotics could be exploited to overcome the otherwise unavoidable loss of viability of beneficial microorganisms during food processes carried out at high temperatures. Microcapsules containing a probiotic strain of L. acidophilus were dispersed (1\% or $2 \%)$ in a starch $(5 \%)$ solution, which covered the surface of bread dough [48]. This technology allowed L. acidophilus to keep its viability after baking, without any negative impact on the taste of bread and texture properties of the crumb. In addition, the edible coating reduced bread crust crispness [48].

\section{Materials and Techniques Used for Probiotic EP}

Commonly, EP are expected to be transparent, flavorless and unable of modifying the sensory properties of food products. However, some applications (e.g., sushi wraps) may require specific sensory properties as lack of evolution of negative organoleptic characteristics. EP are usually composed of two major components: (i) a macromolecule-based substance, biopolymers, (ii) additives as plasticizers, cross-linkers, nanoreinforcements and (iii) precursors as proteins, polysaccharides, lipids or resins 
(Figure 2). The macromolecule-based substance represents the base that, dissolved in a solvent (usually water), forms a cohesive assembly. The plasticizer is added in order to improve mechanical properties of package (e.g., elasticity, toughness, resistance to tearing), so that the package gains flexibility and higher stability [14]. Plasticizers, such as sorbitol, polyethylene glycol, glycerol and sucrose, are commonly needed when the package is composed of proteins and polysaccharides. In some cases, emulsifiers are used, instead of plasticizers, in order to increase the stability of film/coatings, made of lipids and polysaccharides [49]. Due to the materials and/or due to the incorporated active molecules, the EP are meant to protect the food or just to act as a carrier for the active compounds, to reduce contamination, to improve/maintain the food product natural appearance, to enhance the mechanical properties of fragile food products or to boost the appearance and flavor (Figure 2).

MATERIALS

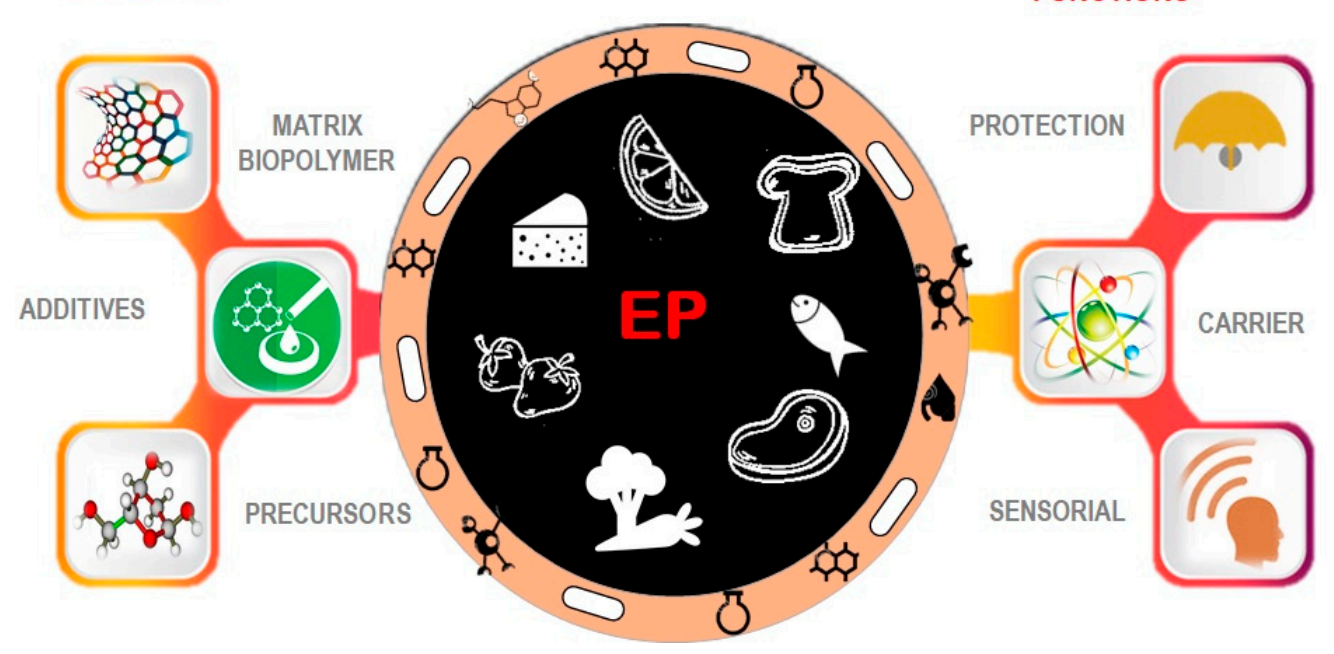

Figure 2. Edible films and coatings components and roles.

Diverse biocompatible components, such as hydrocolloids, lipids and composites, are used in EP preparation [50]. According to their specific purpose, miscellaneous compounds may be exploited for entrapment of probiotics in EP are miscellaneous. In these cases, the package is defined as composite $[5,16]$.

Hydrocolloids include polysaccharides and proteins. Among polysaccharides, cellulose and its derivatives, dextran, inulin, alginate, carrageenan, starch derivatives, pectin derivatives, chitosan, seaweed extracts, and galactomannan are the most utilized for edible films and packages [14,24,51]. All polysaccharides successfully protect food from oxygen, odor, and oil absorption; on the other hand, they show high water permeability [49]. In subsequent paragraphs, a concise presentation of the most utilized materials is made:

Cellulose and cellulose derivate (e.g., methylcellulose and hydroxypropyl methylcellulose) prevent oil absorption from fried food items [52] and have been successfully used for EP-containing probiotics [53-55]. Alginic acid, also known as alginate, may be conveniently applied to meat products, where it considerably delays lipid oxidation [56-58]. Chitosan is obtained from chitin deacetylation and is usually obtained from the exoskeleton of crustaceans and fungal cell walls [59]. The deacetylation process influences the chitosan molecular weight and, in turns its properties (i.e., crystallinity, hydrophobicity, degradation, tensile strength and moisture content) [60,61]. Chitosan shows antimicrobial properties [62,63]. Starch and its derivatives are cost-effective and easy to handle. In addition, they are typically clear, inodorous and insipid $[64,65]$. The starch films and coating characteristics are strongly influenced by the amylose/amilopectin ratio. A strong and flexible film is obtained from a starch rich in amylose content [66]. Pectin, frequently utilized in jams and jellies, was used to produce films and coatings containing probiotics $[67,68]$. 
Proteins are dissolved or dispersed in solvents (i.e., water or ethanol) that are further evaporated in order to obtain the package. The protein-based structure forming process is favored by heat or acid conditions [69,70]. Compared to polysaccharides, proteins have lower vapor permeability.

Lipids may be commonly utilized in the form of waxes, oils, fats, and resins for building EP-entrapping probiotics [71]. Since they are characterized by a high resistance to water penetration, in most cases, the lipids are combined with polysaccharides or proteins [72].

Table 1 summarizes some of the types of composite used in order to obtain EP, the materials and the designated food products with some generic and specific effects.

The materials used for EP may be derived from food industry byproducts, such as whey, corn zein (source of proteins), mung bean or fruit pomace (source of pectin). This represents an environmentally friendly solution and assists in cost reduction. Nevertheless, the utilization of food byproducts in EP could signal consumer mistrust due to confusion between byproducts and wastes.

Extensive applications of mentioned materials has been literally obstructed by some difficulties in the material preparation process $[73,74]$. Most of these difficulties are related to the solubility of the materials in solvents that are accepted in food industry. However, scientists innovate in order to obtain best properties of the EP. An edible biocomposite film was proposed to be obtained directly from psyllium seed, but it was proven that the utilization of seeds husk and husk flour was more suitable [75]. In general, lipids are difficult to apply on the surface of some foods due to their poor adhesion to food products with hydrophilic surfaces [76]. Chitosan can ensure many benefits, such as excellent hydrophilicity, high porosity, big adhesion area, and can be cross-linked to avoid dissolution in acidic solutions $(\mathrm{pH}<2)$. The use of chitosan as material for the entrapment of probiotics has been widely studied, but the too-soft texture and similarities between the density of the EP and that of water (leading to easy float) limits its industrial function. Therefore, efforts have been made to support the structure through the addition of activated clay and crosslinking with glutaraldehyde, which has been demonstrated to permit superior operational stability. However, these alternatives are not suitable for the food industry. Nevertheless, more studies regarding the challenges in the materials preparation process need to be conducted in order to smooth the processes and sustain this environmentally friendly method [77].

In order to sustain the applicability of probiotic EP in the food industry at an industrial scale, new and innovative techniques need to be developed. Nanotechnology and the utilization of nanomaterials is a promising area that can broaden the use of probiotic EP. Formulation of non-nanomaterials in nanosized structures can bring enormous benefits due to the new and unique obtained bioactive properties [78]. The utilization of electrospinning in the preparation of EP materials can be a suitable technique for the restructuration of biopolymers in nanoscale. 
Table 1. Some polysaccharides, proteins, lipids, and composites-based EP for different food products with their generic and specific functions.

\begin{tabular}{|c|c|c|c|c|c|c|}
\hline Ma & erials/Methods & Generic Effects & Specific Composition & Type of Food & Specific Effects & Reference \\
\hline \multirow{6}{*}{ Polysaccharides } & Starch & \multirow{6}{*}{$\begin{array}{l}\text { + colorless } \\
\text { + oil-free appearance } \\
\text { + reduced caloric content } \\
\text { + prolong shelf life } \\
\text { + suitable for fruits, vegetables, meat } \\
\text { + control oxygen transmission } \\
\text { + reduce darkening of the surface } \\
\text { - no moisture barrier } \\
\text { - hydrophilic nature }\end{array}$} & \multirow{2}{*}{$\begin{array}{l}\text { Starch-based coatings with D-glucose, silver nitrate. } \\
\text { Hydroxypropyl methylcellulose (HPMC) and } \\
\text { beeswax coatings. }\end{array}$} & Chicken Sausages & \multirow{3}{*}{$\begin{array}{l}\text { Antimicrobial activity. } \\
\text { Prevent weight loss, sustain fruit firmness, } \\
\text { improved sensory attributes. } \\
\text { Maintain the color, prevent weight loss, trolox } \\
\text { equivalent antioxidant capacity, prevent } \\
\text { microbial growth. }\end{array}$} & [79] \\
\hline & Cellulose and derivatives & & & Cherry tomatoes & & {$[80]$} \\
\hline & Pectin & & $\begin{array}{l}\text { Pectin and sodium alginate coatings with citral and eugenol } \\
\text { essential oils. }\end{array}$ & Raspberries & & [81] \\
\hline & Pullulan & & Pullulan-based coatings with sweet basil extract. & Apples & $\begin{array}{l}\text { Sustain color, appearance and sensory attributes } \\
\text { during hypothermia storage. }\end{array}$ & [82] \\
\hline & Alginates & & Alginate-chitosan and $\mathrm{ZnO}$ nanoparticle & Guavas & Increase the shelf-life of the fruit. & [83] \\
\hline & Chitosan & & Chitosan-based coatings with vacuum packaging. & Beef & $\begin{array}{l}\text { Effects on color preservation and lipid oxidation } \\
\text { during retail presentation. }\end{array}$ & [84] \\
\hline \multirow{4}{*}{ Proteins } & \multirow{2}{*}{ Vegetable-based proteins } & \multirow{4}{*}{$\begin{array}{l}\text { + provide mechanical stability } \\
\text { + good transparency } \\
\text { - not suitable for some diets (vegan) }\end{array}$} & Whey proteins coatings with lysozyme. & Salmon & Overall quality of salmon. & [85] \\
\hline & & & $\begin{array}{l}\text { Gluten and zein coatings with potassium caseinate, rennet } \\
\text { casein, xanthan gum, locust bean additives. }\end{array}$ & Trout Fillets & $\begin{array}{l}\text { Sensorial attributes and the physical } \\
\text { biochemical qualities. }\end{array}$ & [86] \\
\hline & \multirow{2}{*}{ Animal-based proteins } & & Caseinate-based coatings with ascorbic acid additives. & Beef & $\begin{array}{l}\text { Effect of gamma irradiation on microbiological } \\
\text { characteristics of ground beef. }\end{array}$ & [87] \\
\hline & & & Furcellaran-gelatin-based edible coating. & Salmon sushi & $\begin{array}{l}\text { Exhibit good transparency, mechanical and } \\
\text { barrier properties and can be manufactured by } \\
\text { extrusion or casting processes. }\end{array}$ & [88] \\
\hline \multirow{5}{*}{ Fats } & Oils & \multirow{5}{*}{+ reduce water transmission } & $\begin{array}{l}\text { Lipid-based (sunflower oil and chocolate) coating with } \\
\text { stearic acid, polyglycerol. }\end{array}$ & Apple slices & Moisture barrier. & [89] \\
\hline & \multirow{4}{*}{ Waxes } & & Candelilla wax coating with ellagic acid. & Avocado & Antifungal characteristics to enhance shelf life. & [90] \\
\hline & & & Carnauba wax coating. & Eggplant & $\begin{array}{l}\text { Increase in the water vapor resistance and } \\
\text { reduction in weight loss. }\end{array}$ & [91] \\
\hline & & & Candelilla wax coatings with mineral oil. & Guava fruit & $\begin{array}{l}\text { Weight loss ethylene emission, gloss, retention of } \\
\text { the color, firmness. }\end{array}$ & [92] \\
\hline & & & Chitosan-Beeswax coating. & Strawberries & Reduction in weight loss. & [93] \\
\hline \multirow{5}{*}{\multicolumn{2}{|c|}{ Multicomponents/Composites }} & \multirow{5}{*}{$\begin{array}{l}\text { + special tailored for specific } \\
\text { characteristics } \\
\text { + enhance the permeability or } \\
\text { mechanical properties } \\
\text { - may get expensive }\end{array}$} & $\begin{array}{l}\text { Composites of carrageenan and whey protein coatings with } \\
\text { CMC sodium salt, polyethylene glycol, calcium chloride, } \\
\text { glycerol and oxalic acid additives. }\end{array}$ & Apples & Reduce brownness. & [94] \\
\hline & & & Composite of chitosan and gelatin coatings. & Red bell peppers & $\begin{array}{l}\text { Improve firmness, diminish weight loss, and } \\
\text { ethanol concentration. }\end{array}$ & [95] \\
\hline & & & \multirow{3}{*}{$\begin{array}{l}\text { Composite of hydroxypropyl methyl cellulose (HPMC) and } \\
\text { lipid coating with potassium sorbate, sodium benzoate, } \\
\text { sodium propionate, stearic acid, glycerol additives. } \\
\text { Shellac, gelatin and Persian gum. } \\
\text { Hydroxypropyl methylcellulose-lipid composite } \\
\text { edible coatings. }\end{array}$} & Oranges & $\begin{array}{l}\text { Antifungal properties improved during long-term } \\
\text { cold storage. }\end{array}$ & [96] \\
\hline & & & & Orange & Improve permeability characteristics. & [97] \\
\hline & & & & Citrus fruits & Maintain postharvest quality. & [98] \\
\hline
\end{tabular}




\section{Probiotics Viability in EP}

Probiotics may be used in pharmaceutical or food-based products [99,100]. The edible coating or films may be regarded as a carrier of probiotics. The major challenge to be faced by probiotic microorganisms is their resistance to entrapment, an essential prerequisite for their viability in the final product. Only viable probiotics at adequate cell numbers can successfully colonize the colon. Some studies were specifically devoted to investigating the viability of probiotics entrapped in edible coatings/films. Composition and storage temperature affect viability of probiotics in edible coatings/films. Pullulan is a polysaccharide that can be used as a base for EP. A pullulan-based film embedding probiotic lactobacilli (L. reuteri ATCC (American Type Culture Collection) 55730, L. rhamnosus GG ATCC 53103, and L. acidophilus DSM 20079) proved to sustain the viability of probiotics, during 10 and 20 days' storage at room temperature at levels of 10.3 and $4.5 \log \mathrm{CFU} / \mathrm{mL}$, respectively. A similar film, but containing a mixture of pullulan and potato starch, was less effective in maintaining the viability of probiotic lactobacilli. In detail, the higher the starch content, the lower the probiotic viability. However, when lower storage temperature $\left(4^{\circ} \mathrm{C}\right)$ was applied, no differences were found in terms of viability loss between the pullulan- and pullulan/starch-based film. The viability loss did not exceed $10 \%$ even after 30 days of storage [101]. Entrapment of L. rhamnosus GG in a film based on a mixture of starch (from rice and corn) and proteins (bovine gelatin, sodium caseinate, and soy protein) resulted in higher viability of the probiotic strains at refrigeration than at room temperature. The presence of proteins increased viability of L. rhamnosus GG during the film formation process [102]. L. plantarum and Kluyveromyces marxianus incorporated in a film composed of kefiran (a polysaccharide secreted by lactic acid bacteria) and glycerol did not negatively affect the film optical and physical properties. Compared to a suspension, both microorganisms showed better tolerance to acid conditions in the film and maintained their viability through storage at room temperature. In addition, the yeast showed higher resistance to the film-forming procedure than the lactic acid bacterium [103]. B. animalis subsp. lactis BB-12 was incorporated in alginate and gellan (2\% solutions) edible coatings and applied on fresh-cut apple and papaya. Although a viability decrease of the probiotic higher than $85 \%$ was observed, BB- 12 was maintained above the minimum recommended $\left(10^{6} \mathrm{CFU} / \mathrm{g}\right)[46]$.

\section{Synbiotics in EP}

Probiotics may be combined with prebiotic compounds, i.e., substances capable of favoring beneficial microbes in the human gut. The term "synbiotics" is used for indicating products containing at least one probiotic microorganism and one prebiotic substance. Such products may help to maintain the cell viability of probiotics and have been experimented inside edible films. The presence of fructooligosaccharides (FOS) as prebiotic compounds in a methylcellulose-based film containing two probiotic strains (L. delbrueckii subsp. bulgaricus CIDCA 333 and L. plantarum CIDCA 83114) was effective in the protection of both probiotics. However, it had a negative effect in the film forming-process, by reducing the glass transition temperature of the film [66]. Inulin, galacto-oligosaccharide and FOS in chitosan-based film favored viability of probiotic Bifidobacterium infantis ATCC 15697 and Lactobacillus fermentum ATCC 9398. Besides the prebiotic effect, the oligosaccharides increased the extensibility of the film, compared to a prebiotic-free film [104]. Viability of L. rhamnosus GG was monitored during time in a gelatin-based film added with inulin, polydextrose, gluco-oligosaccharides and wheat dextrin. The presence of prebiotic compounds did not impair the film structure. Viability loss was found regardless of the type of prebiotic compound, but especially with film containing gluco-oligosaccharides (about $40 \%$ ) or polydextrose (almost $85 \%$ ). Among the tested prebiotics, inulin allowed to maintain viability of the probiotic strain at acceptable level over 100 days of storage, whereas in the film containing the other compounds an acceptable viability was maintained for a shorter time (63-83 days) [102].

Thus, the limitations and difficulties in the utilization of pro- and prebiotics in EP formulations need to be addresses, despite the fact that very few scientific papers discuss this aspect. The utilization of prebiotics, together with the probiotics may lead to serious changes in the final properties of EP. 
Ensuring low production costs is the main challenge for future EP process and formulation technologies. The exploitation of food-grade raw materials such as native, and physically or enzymatically processed biopolymers, is one example of a method that has the potential to meet the challenge of widening the range of EP types into which probiotic and prebiotic can be favorably incorporated [105]. Novel developments for control release systems from the EP will also provide new possibilities. Negative changes in the EP formulation, that are not affecting the characteristics of food products and ensure the extension of shelf life (i.e., transparency, brightness, etc.) will be accepted by the consumers only if they realize that the benefits related to the presence of prebiotics in the probiotic EP are greater than the characteristic related to the food appearance.

\section{Antimicrobial Effects of Probiotics Incorporated in EP}

Besides their positive effects on human health, probiotic microorganisms incorporated in EP could protect food from pathogenic bacteria, leading to increased food safety. They could also inhibit spoilage microorganisms, thus extend the shelf-life of food. A probiotic strain belonging to Lactobacillus sakei was embedded in a sodium caseinate-based film through either direct incorporation in the film-forming suspension or by spraying on an already-formed film. The film, and its counterpart not containing probiotic lactobacilli, were applied on plates of tryptic soy agar on fresh beef slices, which were inoculated with Listeria monocytogenes. During four days of incubation on plates, the probiotic strain increased of one log cycle its cell density. L. monocytogenes decreased (3.0-3.6 log cycles) during the 12 days of storage. In the beef slices stored at $4{ }^{\circ} \mathrm{C}$ for 21 days, L. sakei cell density was higher than $6 \log \mathrm{CFU} / \mathrm{cm}^{2}$. In addition, the cell density of the pathogenic bacterium was two log cycles lower than in the probiotic-free film [106]. In the presented study, it can be observed that the presence pf probiotics from lactobacillus species negatively influenced the multiplication of L. monocytogenes on the beef slices by producing bacteriocin-like substance. Thus, the production of this substance was nonexistent after a long period of time. This fact can be explained by the death of lactobacillus as an effect of the environmental conditions and lack of nutrients.

A similar study that echoes the above-presented results is an alginate-based film containing Carnobacterium maltaromaticum, a potential probiotic bacterium normally found as commensal of various fish species $[107,108]$, was applied on smoked salmon, inoculated with L. monocytogenes at $4 \log \mathrm{CFU} / \mathrm{cm}^{2}$. This film had a bacteriostatic effect towards L. monocytogenes during 28 days of storage at $4{ }^{\circ} \mathrm{C}$ [109]. The authors of the study declare that the antibacterial effect can be explained due to the neutralized supernatant and therefore was not due to acidity or $\mathrm{pH}$.

A gelatin-based coating containing probiotic strains of L. acidophilus and Bifidobacterium bifidum was applied to hake (Merluccius merluccius). Both probiotic strains maintained their initial level $\left(10^{9} \mathrm{CFU} / \mathrm{mL}\right)$ of viability for 6 days of storage at $2{ }^{\circ} \mathrm{C}$. The spoilage agent Shewanella putrefaciens, typically producer of $\mathrm{H}_{2} \mathrm{~S}$, was found in coated hake at significantly lower counts than the uncoated hake. However, the antibacterial effect had no relevant link to the presence of probiotics in the edible package. Treatment of coated hake through high hydrostatic pressure $\left(200 \mathrm{MPa}\right.$ for $10 \mathrm{~min}$ at $\left.20^{\circ} \mathrm{C}\right)$ proved to be effective in decreasing the spoiling agent, but had no effect on the viability of probiotics [98].

The ability of an agar-based film, incorporating green tea extract and two probiotic strains (Lactobacillus paracasei L26 and B. animalis subsp. lactis B94), to inhibit two spoiling bacteria was investigated in hake fillets. The spoiling agents, S. putrefaciens and Photobacterium phosphoreum were deliberately added $\left(10^{3}-10^{4} \mathrm{CFU} / \mathrm{g}\right)$ to hake fillets, prior to film application. The results showed that probiotic bacteria migrated from the film to fish and that fish wrapped in the film displayed lower values of spoilage indicators compared to untreated fish (e.g., $\mathrm{pH}$, count of $\mathrm{H}_{2} \mathrm{~S}$-producing bacteria, concentration of trimethylamine). Overall, the use of this probiotic film extended the shelf life of hake fillets for at least one week [110].

The type of material constituting the edible package affects probiotics viability and their antimicrobial activity. A probiotic strain of L. plantarum was embedded in an edible film based on sodium caseinate, pea protein, methylcellulose or hydroxymethylcellulose [54]. The probiotic strain 
showed higher viability in protein than in cellulose-based film. Interestingly, when applied in the cellulose-based film, L. plantarum produced higher levels of bacteriocin, resulting in the total inactivation of Listeria innocua during 8 days of storage at refrigerated temperature [54].

When incorporated in sodium caseinate- or methylcellulose-based film, L. acidophilus displayed higher viability than L. reuteri. After three days of storage, higher antilisterial activity was found for the methylcellulose-based film than for the one made of sodium caseinate. Compared to similar films without probiotic lactobacilli, Listeria sp. decreased by about $1.5 \log$ cycle after 12 days of storage [111].

Alginate, whey proteins, or a mixture thereof were used for forming an edible coating containing L. rhamnosus GG and was applied to bread [43]. During the two drying processes considered $\left(60^{\circ} \mathrm{C}\right.$ for $10 \mathrm{~min}, 180^{\circ} \mathrm{C}$ for $2 \mathrm{~min}$ ), the composite-based coating provided L. rhamnosus GG with higher protection, with respect to alginate- or whey proteins-based coating. However, following simulated gastrointestinal digestion, the highest cell density of L. rhamnosus GG $\left(10^{6} \mathrm{CFU} / \mathrm{g}\right)$ was found in the bread coated with alginate [43].

The antibacterial activity of probiotics embedded in EP is limited due to the specific activity of the probiotic metabolites. This fact can explain why same probiotic strain act as antimicrobials against certain pathogens and some have no influence. Nevertheless, as seen [54], the material used for the incorporation of probiotics has a great impact regarding the antimicrobial activity of the probiotic strain. This activity modulation can be correlated to the permeability of the EP for the antimicrobials metabolites produced by the probiotic cells and by the material capacity to protect the active cells.

\section{Concluding Remarks}

Nowadays, the increasing consciousness of consumers about the link between dietary habits and health fosters the market of food containing probiotic microorganisms. EP technologies allow us to broaden the fields of application of probiotics to unexplored food items (e.g., baked goods). Overall, at an industrial scale, the number of applications of edible coatings/films containing probiotics is much lower than that of research studies carried out in the laboratory. One of the major challenges to be faced in order to achieve a wider industrial application is to obtain the perfect combination of materials, technologies and probiotic strains, tailored to specific foods and consumers' needs, and at an acceptable cost. Another challenge is in the need to maintain a high cell density of probiotics during the formation process of EP and, especially, after ingestion. This is a prerequisite to impact human health positively. Future research efforts should be dedicated to these two challenges. In addition, a higher number of studies about the health benefits of EP are essential.

Author Contributions: O.L.P. researched studies and wrote the manuscript; C.R.P. researched studies and collected data, M.D., D.C.V., S.A.S., F.V.D., provided ideas, discussion, corrected the manuscript, F.M. and R.S. revised and corrected the manuscript and supervised this project. All authors have read and agreed to the published version of the manuscript.

Funding: The publication was supported by funds from the National Research Development Projects to finance excellence (PFE)-37/2018-2020 granted by the Romanian Ministry of Research and Innovation.

Acknowledgments: We kindly thank Marian Rodion Pop for image processing.

Conflicts of Interest: The authors declare no conflicts of interest.

\section{References}

1. Gere, A.; Radványi, D.; Moskowitz, H. Consumer Perspectives about innovations in traditional foods. In Innovations in Traditional Foods; Galanakis, C.M., Ed.; Woodhead Publishing: Cambridge, UK, 2019; pp. 53-84.

2. Quirós-Sauceda, A.E.; Ayala-Zavala, J.F.; Olivas, G.I.; González-Aguilar, G.A. Edible coatings as encapsulating matrices for bioactive compounds: A review. J. Food. Sci. Technol. 2014, 51, 1674-1685. [CrossRef] [PubMed]

3. Salgado, P.R.; Ortiz, C.M.; Musso, Y.S.; Di Giorgio, L.; Mauri, A.N. Edible films and coatings containing bioactives. Curr. Opin. Dood Sci. 2015, 5, 86-92. [CrossRef]

4. Guilbert, S.; Gontard, N.; Cuq, B. Technology and applications of edible protective films. Packag. Technol. Sci. 1995, 8, 339-346. [CrossRef] 
5. Galus, S.; Kadzińska, J. Food applications of emulsion-based edible films and coatings. Trends Food Sci. Technol. 2015, 45, 273-283. [CrossRef]

6. Paul, S.K. Edible films and coatings for fruits and vegetables. In Reference Module in Materials Science and Materials Engineering; Elsevier: Amsterdam, The Netherlands, 2019.

7. Parente Ribeiro Cerqueira, M.Â. Edible packaging. In Encyclopedia of Food Chemistry; Melton, L., Shahidi, F., Varelis, P., Eds.; Academic Press: Oxford, UK, 2019; pp. 173-176.

8. Mkandawire, M.; Aryee, A.N.A. Resurfacing and modernization of edible packaging material technology. Curr. Opin. Food Sci. 2018, 19, 104-112. [CrossRef]

9. McMillin, K.W. Advancements in meat packaging. Meat Sci. 2017, 132, 153-162. [CrossRef]

10. Schumann, B.; Schmid, M. Packaging concepts for fresh and processed meat-Recent progresses. Innov. Food Sci. Emerg. Technol. 2018, 47, 88-100. [CrossRef]

11. Min, S.; Harris, L.J.; Krochta, J.M. Listeria monocytogenes inhibition by whey protein films and coatings incorporating the lactoperoxidase system. J. Food Sci. 2005, 70, m317-m324. [CrossRef]

12. Trinetta, V. Edible packaging. In Reference Module in Food Science; Elsevier: Amsterdam, The Netherlands, 2016.

13. Rodriguez-Turienzo, L.; Cobos, A.; Moreno, V.; Caride, A.; Vieites, J.M.; Diaz, O. Whey protein-based coatings on frozen Atlantic salmon (Salmo salar): Influence of the plasticiser and the moment of coating on quality preservation. Food Chem. 2011, 128, 187-194. [CrossRef]

14. Valencia-Chamorro, S.A.; Palou, L.; Del Rio, M.A.; Perez-Gago, M.B. Antimicrobial edible films and coatings for fresh and minimally processed fruits and vegetables: A review. Crit. Rev. Food Sci. Nutr. 2011, 51, 872-900. [CrossRef]

15. Cagri, A.; Ustunol, Z.; Ryser, E.T. Antimicrobial edible films and coatings. J. Food Protect. 2004, 67, 833-848. [CrossRef] [PubMed]

16. Hassan, B.; Chatha, S.A.S.; Hussain, A.I.; Zia, K.M.; Akhtar, N. Recent advances on polysaccharides, lipids and protein based edible films and coatings: A review. Int. J. Biol. Macromol. 2018, 109, 1095-1107. [CrossRef] [PubMed]

17. Ehteshami, S.; Abdollahi, F.; Ramezanian, A.; Dastjerdi, A.M.; Rahimzadeh, M. Enhanced chilling tolerance of pomegranate fruit by edible coatings combined with malic and oxalic acid treatments. Sci. Hortic. 2019, 250, 388-398. [CrossRef]

18. Ares, G.; Giménez, A.; Deliza, R. Methodological approaches for measuring consumer-perceived well-being in a food-related context. In Methods in Consumer Research; Ares, G., Varela, P., Eds.; Woodhead Publishing: Cambridge, UK, 2018; Volume 2, pp. 183-200.

19. Li, X.-Y.; Du, X.-L.; Liu, Y.; Tong, L.-J.; Wang, Q.; Li, J.-L. Rhubarb extract incorporated into an alginate-based edible coating for peach preservation. Sci. Hortic. 2019, 257, 108685. [CrossRef]

20. Guo, M.; Yadav, M.P.; Jin, T.Z. Antimicrobial edible coatings and films from micro-emulsions and their food applications. Int. J. Food Microbiol. 2017, 263, 9-16. [CrossRef] [PubMed]

21. Erginkaya, Z.; Kalkan, S.; Ünal, E. Use of antimicrobial edible films and coatings as packaging materials for food safety. In Food Processing: Strategies for Quality Assessment; Malik, A., Erginkaya, Z., Ahmad, S., Erten, H., Eds.; Springer: New York, NY, USA, 2014; pp. 261-295.

22. Benbettaïeb, N.; Debeaufort, F.; Karbowiak, T. Bioactive edible films for food applications: Mechanisms of antimicrobial and antioxidant activity. Crit. Rev. Food Sci. Nutr. 2018, 59, 3431-3455. [CrossRef] [PubMed]

23. Dwivedi, P.; Singh, M.; Sehra, N.; Pandey, N.; Sangwan, R.S.; Mishra, B.B. Processing of wet Kinnow mandarin (Citrus reticulata) fruit waste into novel Brønsted acidic ionic liquids and their application in hydrolysis of sucrose. Bioresour. Technol. 2018, 250, 621-624. [CrossRef]

24. Otoni, C.G.; Avena-Bustillos, R.J.; Azeredo, H.M.C.; Lorevice, M.V.; Moura, M.R.; Mattoso, L.H.C.; McHugh, T.H. Recent advances on edible films based on fruits and vegetables-A review. Compr. Rev. Food Sci. Food Saf. 2017, 16, 1151-1169. [CrossRef]

25. Odila Pereira, J.; Soares, J.; Sousa, S.; Madureira, A.R.; Gomes, A.; Pintado, M. Edible films as carrier for lactic acid bacteria. LWT 2016, 73, 543-550. [CrossRef]

26. Realini, C.E.; Marcos, B. Active and intelligent packaging systems for a modern society. Meat Sci. 2014, 98, 404-419. [CrossRef]

27. Müller, P.; Schmid, M. Intelligent packaging in the food sector: A brief overview. Foods 2019, 8, 16. [CrossRef] [PubMed] 
28. Bagchi, T. Traditional food \& modern lifestyle: Impact of probiotics. Indian J. Med. Res. 2014, 140, $333-335$. [PubMed]

29. Pop, O.L.; Socaci, S.A.; Suharoschi, R.; Vodnar, D.C. Pro and prebiotics foods that modulate human health. In The Role of Alternative and Innovative Food Ingredients and Products in Consumer Wellness; Elesvier: Amsterdam, The Netherlands, 2019; p. 283.

30. Yahfoufi, N.; Mallet, J.F.; Graham, E.; Matar, C. Role of probiotics and prebiotics in immunomodulation. Curr. Opin. Food Sci. 2018, 20, 82-91. [CrossRef]

31. Scheid, M.M.A.; Moreno, Y.M.F.; Maróstica Junior, M.R.; Pastore, G.M. Effect of prebiotics on the health of the elderly. Food Res. Int. 2013, 53, 426-432. [CrossRef]

32. Pop, O.L.; Salanță, L.-C.; Pop, C.R.; Coldea, T.; Socaci, S.A.; Suharoschi, R.; Vodnar, D.C. Prebiotics and dairy applications. In Dietary Fiber: Properties, Recovery, and Applications; Galanakis, C.M., Ed.; Academic Press: Cambridge, MA, USA, 2019; pp. 247-277.

33. Araya, M.M.L.; Reid, G.; Sanders, M.E.; Stanton, C.; Pineiro, M. Joint FAO/WHO Working Group Report on Drafting Guidelines for the Evaluation of Probiotics in Food; World Health Organization, Food and Agriculture Organization of the United Nations: London, ON, Canada, 2002.

34. Ogier, J.C.; Serror, P. Safety assessment of dairy microorganisms: The Enterococcus genus. Int. J. Food Microbiol. 2008, 126, 291-301. [CrossRef] [PubMed]

35. Salminen, S.; von Wright, A.; Morelli, L.; Marteau, P.; Brassart, D.; de Vos, W.M.; Fonden, R.; Saxelin, M.; Collins, K.; Mogensen, G.; et al. Demonstration of safety of probiotics-A review. Int. J. Food Microbiol. 1998, 44, 93-106. [CrossRef]

36. Danneskiold-Samsøe, N.B.; Dias de Freitas Queiroz Barros, H.; Santos, R.; Bicas, J.L.; Cazarin, C.B.B.; Madsen, L.; Kristiansen, K.; Pastore, G.M.; Brix, S.; Maróstica Júnior, M.R. Interplay between food and gut microbiota in health and disease. Food Res. Int. 2019, 115, 23-31. [CrossRef]

37. Mohanty, D.; Misra, S.; Mohapatra, S.; Sahu, P.S. Prebiotics and synbiotics: Recent concepts in nutrition. Food Biosci. 2018, 26, 152-160. [CrossRef]

38. Rezazadeh, L.; Gargari, B.P.; Jafarabadi, M.A.; Alipour, B. Effects of probiotic yogurt on glycemic indexes and endothelial dysfunction markers in patients with metabolic syndrome. Nutrition 2019, 62, 162-168. [CrossRef]

39. Alizadeh Behbahani, B.; Noshad, M.; Falah, F. Inhibition of Escherichia coli adhesion to human intestinal Caco-2 cells by probiotic candidate Lactobacillus plantarum strain L15. Microb. Pathog. 2019, 136, 103677. [CrossRef]

40. Martin Manuel, P.; Elena, B.; Carolina, M.G.; Gabriela, P. Oral probiotics supplementation can stimulate the immune system in a stress process. J. Nutr. Intermed. Metab. 2017, 8, 29-40. [CrossRef]

41. Joshi, D.; Roy, S.; Banerjee, S. Prebiotics: A functional food in health and disease. In Natural Products and Drug Discovery; Mandal, S.C., Mandal, V., Konishi, T., Eds.; Elsevier: Amsterdam, The Netherlands, 2018; pp. 507-523.

42. Duncan, S.H.; Flint, H.J. Probiotics and prebiotics and health in ageing populations. Maturitas 2013, 75, 44-50. [CrossRef] [PubMed]

43. Soukoulis, C.; Behboudi-Jobbehdar, S.; Yonekura, L.; Parmenter, C.; Fisk, I.D. Stability of Lactobacillus rhamnosus GG in prebiotic edible films. Food Chem. 2014, 159, 302-308. [CrossRef] [PubMed]

44. Majid, I.; Ahmad Nayik, G.; Mohammad Dar, S.; Nanda, V. Novel food packaging technologies: Innovations and future prospective. J. Saudi Soc. Agric. Sci. 2018, 17, 454-462. [CrossRef]

45. Jantzen, M.; Göpel, A.; Beermann, C. Direct spray drying and microencapsulation of probiotic Lactobacillus reuteri from slurry fermentation with whey. J. Appl. Microbiol. 2013, 115, 1029-1036. [PubMed]

46. Tapia, M.S.; Rojas-Grau, M.A.; Rodriguez, F.J.; Ramirez, J.; Carmona, A.; Martin-Belloso, O. Alginate- and gellan-based edible films for probiotic coatings on fresh-cut fruits. J. Food Sci. 2007, 72, E190-E196. [CrossRef]

47. Tahir, H.E.; Xiaobo, Z.; Mahunu, G.K.; Arslan, M.; Abdalhai, M.; Zhihua, L. Recent developments in gum edible coating applications for fruits and vegetables preservation: A review. Carbohydr. Polym. 2019, 224, 115141. [CrossRef]

48. Altamirano-Fortoul, R.; Moreno-Terrazas, R.; Quezada-Gallo, A.; Rosell, C.M. Viability of some probiotic coatings in bread and its effect on the crust mechanical properties. Food Hydrocoll. 2012, 29, 166-174. [CrossRef]

49. Ramos, O.L.; Fernandes, J.C.; Silva, S.I.; Pintado, M.E.; Malcata, F.X. Edible films and coatings from whey proteins: A review on formulation, and on mechanical and bioactive properties. Crit. Rev. Food. Sci. Nutr. 2012, 52, 533-552. [CrossRef] 
50. Rojas-Graü, M.A.; Soliva-Fortuny, R.; Martín-Belloso, O. Edible coatings to incorporate active ingredients to fresh-cut fruits: A review. Trends Food Sci. Technol. 2009, 20, 438-447. [CrossRef]

51. Cerqueira, M.A.; Bourbon, A.I.; Pinheiro, A.C.; Martins, J.T.; Souza, B.W.S.; Teixeira, J.A.; Vicente, A.A. Galactomannans use in the development of edible films/coatings for food applications. Trends Food Sci. Technol. 2011, 22, 662-671. [CrossRef]

52. Singh, P.; Magalhães, S.; Alves, L.; Antunes, F.; Miguel, M.; Lindman, B.; Medronho, B. Cellulose-based edible films for probiotic entrapment. Food Hydrocoll. 2019, 88, 68-74. [CrossRef]

53. Tavera-Quiroz, M.J.; Romano, N.; Mobili, P.; Pinotti, A.; Gómez-Zavaglia, A.; Bertola, N. Green apple baked snacks functionalized with edible coatings of methylcellulose containing Lactobacillus plantarum. J. Funct. Food 2015, 16, 164-173. [CrossRef]

54. Sánchez-González, L.; Quintero Saavedra, J.I.; Chiralt, A. Physical properties and antilisterial activity of bioactive edible films containing Lactobacillus plantarum. Food Hydrocoll. 2013, 33, 92-98. [CrossRef]

55. Romano, N.; Tavera-Quiroz, M.J.; Bertola, N.; Mobili, P.; Pinotti, A.; Gómez-Zavaglia, A. Edible methylcellulosebased films containing fructo-oligosaccharides as vehicles for lactic acid bacteria. Food Res. Int. 2014, 64, 560-566. [CrossRef]

56. Tavassoli-Kafrani, E.; Shekarchizadeh, H.; Masoudpour-Behabadi, M. Development of edible films and coatings from alginates and carrageenans. Carbohydr. Polym. 2016, 137, 360-374. [CrossRef]

57. Tapia, M.S.; Rojas-Graü, M.A.; Carmona, A.; Rodríguez, F.J.; Soliva-Fortuny, R.; Martin-Belloso, O. Use of alginate- and gellan-based coatings for improving barrier, texture and nutritional properties of fresh-cut papaya. Food Hydrocoll. 2008, 22, 1493-1503. [CrossRef]

58. Varela, P.; Fiszman, S.M. Hydrocolloids in fried foods. A review. Food Hydrocoll. 2011, 25, 1801-1812. [CrossRef]

59. Elsabee, M.Z.; Abdou, E.S. Chitosan based edible films and coatings: A review. Mater. Sci. Eng. C 2013, 33, 1819-1841. [CrossRef]

60. Martínez-Camacho, A.P.; Cortez-Rocha, M.O.; Ezquerra-Brauer, J.M.; Graciano-Verdugo, A.Z.; Rodriguez-Félix, F; Castillo-Ortega, M.M.; Yépiz-Gómez, M.S.; Plascencia-Jatomea, M. Chitosan composite films: Thermal, structural, mechanical and antifungal properties. Carbohydr. Polym. 2010, 82, 305-315. [CrossRef]

61. Park, S.Y.; Marsh, K.S.; Rhim, J.W. Characteristics of different molecular weight chitosan films affected by the type of organic solvents. J. Food Sci. 2002, 67, 194-197. [CrossRef]

62. Raafat, D.; Sahl, H.G. Chitosan and its antimicrobial potential-A critical literature survey. Microb. Biotechnol. 2009, 2, 186-201. [CrossRef] [PubMed]

63. Salama, H.E.; Abdel Aziz, M.S.; Sabaa, M.W. Novel biodegradable and antibacterial edible films based on alginate and chitosan biguanidine hydrochloride. Int. J. Biol. Macromol. 2018, 116, 443-450. [CrossRef] [PubMed]

64. Galindez, A.; Daza, L.D.; Homez-Jara, A.; Eim, V.S.; Váquiro, H.A. Characterization of ulluco starch and its potential for use in edible films prepared at low drying temperature. Carbohydr. Polym. 2019, 215, 143-150. [CrossRef]

65. Thakur, R.; Pristijono, P.; Bowyer, M.; Singh, S.P.; Scarlett, C.J.; Stathopoulos, C.E.; Vuong, Q.V. A starch edible surface coating delays banana fruit ripening. LWT 2019, 100, 341-347. [CrossRef]

66. Arvanitoyannis, I.; Biliaderis, C.G.; Ogawa, H.; Kawasaki, N. Biodegradable films made from low-density polyethylene (LDPE), rice starch and potato starch for food packaging applications: Part 1. Carbohydr. Polym. 1998, 36, 89-104. [CrossRef]

67. Moalemiyan, M.; Ramaswamy, H.S.; Maftoonazad, N. Pectin-based edible coating for shelf-life extension of ataulfo mango. J. Food Process Eng. 2012, 35, 572-600. [CrossRef]

68. Espitia, P.J.P.; Du, W.-X.; de Avena-Bustillos, R.J.; de Soares, N.F.F.; McHugh, T.H. Edible films from pectin: Physical-mechanical and antimicrobial properties-A review. Food Hydrocoll. 2014, 35, 287-296. [CrossRef]

69. Chiralt, A.; González-Martínez, C.; Vargas, M.; Atarés, L. 18-Edible films and coatings from proteins. In Proteins in Food Processing, 2nd ed.; Yada, R.Y., Ed.; Woodhead Publishing: Cambridge, UK, 2018; pp. 477-500.

70. Galanakis, C.M. Preface. In Proteins: Sustainable Source, Processing and Applications; Galanakis, C.M., Ed.; Academic Press: Cambridge, MA, USA, 2019; pp. ix-xi.

71. Rhim, J.W.; Shellhammer, T.H. 21—Lipid-based edible films and coatings. In Innovations in Food Packaging; Han, J.H., Ed.; Academic Press: London, UK, 2005; pp. 362-383.

72. Enujiugha, V.N.; Oyinloye, A.M. Protein-lipid interactions and the formation of edible films and coatings. In Encyclopedia of Food Chemistry; Melton, L., Shahidi, F., Varelis, P., Eds.; Academic Press: Oxford, UK, 2019; pp. 478-482. 
73. Xu, A.; Chen, L.; Wang, J. Functionalized Imidazalium carboxylates for enhancing practical applicability in cellulose processing. Macromolecules 2018, 51, 4158-4166. [CrossRef]

74. Xu, A.; Guo, X.; Zhang, Y.; Li, Z.; Wang, J. Efficient and sustainable solvents for lignin dissolution: Aqueous choline carboxylate solutions. Green Chem. 2017, 19, 4067-4073. [CrossRef]

75. Tóth, A.; Halász, K. Characterization of edible biocomposite films directly prepared from psyllium seed husk and husk flour. Food Pack. Shelf Life 2019, 20, 100299. [CrossRef]

76. Arnon-Rips, H.; Poverenov, E. Improving food products' quality and storability by using Layer by Layer edible coatings. Trends Food Sci. Technol. 2018, 75, 81-92. [CrossRef]

77. Lopez-Rubio, A.; Gavara, R.; Lagaron, J.M. Bioactive packaging: Turning foods into healthier foods through biomaterials. Trends Food Sci. Technol. 2006, 17, 567-575. [CrossRef]

78. Torres-Giner, S.; Perez-Masia, R.; Lagaron, J.M. A review on electrospun polymer nanostructures as advanced bioactive platforms. Polym. Eng. Sci. 2016, 56, 500-527. [CrossRef]

79. Moreno, O.; Atarés, L.; Chiralt, A.; Cruz-Romero, M.C.; Kerry, J. Starch-gelatin antimicrobial packaging materials to extend the shelf life of chicken breast fillets. LWT 2018, 97, 483-490. [CrossRef]

80. Fagundes, C.; Palou, L.; Monteiro, A.R.; Pérez-Gago, M.B. Hydroxypropyl methylcellulose-beeswax edible coatings formulated with antifungal food additives to reduce alternaria black spot and maintain postharvest quality of cold-stored cherry tomatoes. Sci. Hortic. 2015, 193, 249-257. [CrossRef]

81. Guerreiro, A.C.; Gago, C.M.L.; Faleiro, M.L.; Miguel, M.G.C.; Antunes, M.D.C. The effect of alginate-based edible coatings enriched with essential oils constituents on Arbutus unedo L. fresh fruit storage. Postharvest Biol. Technol. 2015, 100, 226-233. [CrossRef]

82. Synowiec, A.; Gniewosz, M.; Kraśniewska, K.; Przybył, J.L.; Bączek, K.; Wẹglarz, Z. Antimicrobial and antioxidant properties of pullulan film containing sweet basil extract and an evaluation of coating effectiveness in the prolongation of the shelf life of apples stored in refrigeration conditions. Innov. Food Sci. Emerg. 2014, 23, 171-181. [CrossRef]

83. Arroyo, B.J.; Bezerra, A.C.; Oliveira, L.L.; Arroyo, S.J.; de Melo, E.A.; Santos, A.M.P. Antimicrobial active edible coating of alginate and chitosan add $\mathrm{ZnO}$ nanoparticles applied in guavas (Psidium guajava L.). Food Chem. 2019, 125566. [CrossRef]

84. Duran, A.; Kahve, H.I. The effect of chitosan coating and vacuum packaging on the microbiological and chemical properties of beef. Meat Sci. 2019, 107961. [CrossRef]

85. Boyac1, D.; Korel, F.; Yemenicioğlu, A. Development of activate-at-home-type edible antimicrobial films: An example $\mathrm{pH}$-triggering mechanism formed for smoked salmon slices using lysozyme in whey protein films. Food Hydrocoll. 2016, 60, 170-178. [CrossRef]

86. Kilincceker, O.; Dogan, İ.S.; Kucukoner, E. Effect of edible coatings on the quality of frozen fish fillets. $L W T$ 2009, 42, 868-873. [CrossRef]

87. Lacroix, M.; Ouattara, B.; Saucier, L.; Giroux, M.; Smoragiewicz, W. Effect of gamma irradiation in presence of ascorbic acid on microbial composition and TBARS concentration of ground beef coated with an edible active coating. Radiat. Phys. Chem. 2004, 71,73-77. [CrossRef]

88. Kulawik, P.; Jamróz, E.; Zając, M.; Guzik, P.; Tkaczewska, J. The effect of furcellaran-gelatin edible coatings with green and pu-erh tea extracts on the microbiological, physicochemical and sensory changes of salmon sushi stored at $4{ }^{\circ} \mathrm{C}$. Food Control 2019, 100, 83-91. [CrossRef]

89. Khan, M.K.I.; Cakmak, H.; Tavman, Ş.; Schutyser, M.; Schroën, K. Anti-browning and barrier properties of edible coatings prepared with electrospraying. Innov. Food Sci. Emerg. 2014, 25, 9-13. [CrossRef]

90. Saucedo-Pompa, S.; Rojas-Molina, R.; Aguilera-Carbó, A.F.; Saenz-Galindo, A.; de Garza, H.L.; Jasso-Cantú, D.; Aguilar, C.N. Edible film based on candelilla wax to improve the shelf life and quality of avocado. Food Res. Int. 2009, 42, 511-515. [CrossRef]

91. Singh, S.; Khemariya, P.; Rai, A.; Rai, A.C.; Koley, T.K.; Singh, B. Carnauba wax-based edible coating enhances shelf-life and retain quality of eggplant (Solanum melongena) fruits. LWT 2016, 74, 420-426. [CrossRef]

92. Tomás, S.A.; Bosquez-Molina, E.; Stolik, S.; Sánchez, F. Effects of mesquite gum-candelilla wax based edible coatings on the quality of guava fruit (Psidium guajava L.). J. Phys. IV Fr. 2005, 125, 889-892. [CrossRef]

93. Velickova, E.; Winkelhausen, E.; Kuzmanova, S.; Alves, V.D.; Moldão-Martins, M. Impact of chitosan-beeswax edible coatings on the quality of fresh strawberries (Fragaria ananassa cv Camarosa) under commercial storage conditions. LWT 2013, 52, 80-92. [CrossRef] 
94. Lee, J.Y.; Park, H.J.; Lee, C.Y.; Choi, W.Y. Extending shelf-life of minimally processed apples with edible coatings and antibrowning agents. LWT 2003, 36, 323-329. [CrossRef]

95. Poverenov, E.; Zaitsev, Y.; Arnon, H.; Granit, R.; Alkalai-Tuvia, S.; Perzelan, Y.; Weinberg, T.; Fallik, E. Effects of a composite chitosan-gelatin edible coating on postharvest quality and storability of red bell peppers. Postharvest Biol. Technol. 2014, 96, 106-109. [CrossRef]

96. Valencia-Chamorro, S.A.; Pérez-Gago, M.B.; del Río, M.Á.; Palou, L. Effect of antifungal hydroxypropyl methylcellulose (HPMC)-lipid edible composite coatings on postharvest decay development and quality attributes of cold-stored 'Valencia' oranges. Postharvest Biol. Technol. 2009, 54, 72-79. [CrossRef]

97. Khorram, F.; Ramezanian, A.; Hosseini, S.M.H. Shellac, gelatin and Persian gum as alternative coating for orange fruit. Sci. Hortic. 2017, 225, 22-28. [CrossRef]

98. Guimarães, J.E.R.; de la Fuente, B.; Pérez-Gago, M.B.; Andradas, C.; Carbó, R.; Mattiuz, B.-H.; Palou, L. Antifungal activity of GRAS salts against Lasiodiplodia theobromae in vitro and as ingredients of hydroxypropyl methylcellulose-lipid composite edible coatings to control Diplodia stem-end rot and maintain postharvest quality of citrus fruit. Int. J. Food Microbiol. 2019, 301, 9-18. [CrossRef] [PubMed]

99. Lin, D.C. Probiotics as functional foods. Nutr. Clin. Pract. 2003, 18, 497-506. [CrossRef]

100. Vieira da Silva, B.; Barreira, J.C.M.; Oliveira, M.B.P.P. Natural phytochemicals and probiotics as bioactive ingredients for functional foods: Extraction, biochemistry and protected-delivery technologies. Trends Food Sci. Technol. 2016, 50, 144-158. [CrossRef]

101. Kanmani, P.; Lim, S.T. Development and characterization of novel probiotic-residing pullulan/starch edible films. Food Chem. 2013, 141, 1041-1049. [CrossRef]

102. Soukoulis, C.; Singh, P.; Macnaughtan, W.; Parmenter, C.; Fisk, I.D. Compositional and physicochemical factors governing the viability of Lactobacillus rhamnosus GG embedded in starch-protein based edible films. Food Hydrocoll. 2016, 52, 876-887. [CrossRef]

103. Piermaria, J.; Diosma, G.; Aquino, C.; Garrote, G.; Abraham, A. Edible kefiran films as vehicle for probiotic microorganisms. Innov. Food Sci. Emerg. 2015, 32, 193-199. [CrossRef]

104. Tang, Y.; Xie, F.; Zhang, D.; Zhu, M.; Liu, L.; Liu, P.; Gu, C. Physical properties and prebiotic activity of maize starch-based functional films. Starch Stärke 2015, 67, 124-131. [CrossRef]

105. Mattila-Sandholm, T.; Myllärinen, P.; Crittenden, R.; Mogensen, G.; Fondén, R.; Saarela, M. Technological challenges for future probiotic foods. Int. Dairy J. 2002, 12, 173-182. [CrossRef]

106. Gialamas, H.; Zinoviadou, K.G.; Biliaderis, C.G.; Koutsoumanis, K.P. Development of a novel bioactive packaging based on the incorporation of Lactobacillus sakei into sodium-caseinate films for controlling Listeria monocytogenes in foods. Food Res. Int. 2010, 43, 2402-2408. [CrossRef]

107. Socaciu, M.-I.; Semeniuc, C.A.; Vodnar, D.C. Edible Films and coatings for fresh fish packaging: focus on quality changes and shelf-life extension. Coatings 2018, 8, 366. [CrossRef]

108. Lauzon, H.L.; Pérez-Sánchez, T.; Merrifield, D.L.; Ringø, E.; Balcázar, J.L. Probiotic Applications in Cold Water Fish. Species. In Aquaculture Nutrition; John and Wiley and Sons: Hoboken, NJ, USA, 2014; pp. $223-252$.

109. Concha-Meyer, A.; Schöbitz, R.; Brito, C.; Fuentes, R. Lactic acid bacteria in an alginate film inhibit Listeria monocytogenes growth on smoked salmon. Food Control 2011, 22, 485-489. [CrossRef]

110. López de Lacey, A.M.; López-Caballero, M.E.; Montero, P. Agar films containing green tea extract and probiotic bacteria for extending fish shelf-life. LWT 2014, 55, 559-564. [CrossRef]

111. Sánchez-González, L.; Quintero Saavedra, J.I.; Chiralt, A. Antilisterial and physical properties of biopolymer films containing lactic acid bacteria. Food Control 2014, 35, 200-206. [CrossRef]

(C) 2019 by the authors. Licensee MDPI, Basel, Switzerland. This article is an open access article distributed under the terms and conditions of the Creative Commons Attribution (CC BY) license (http://creativecommons.org/licenses/by/4.0/). 